\title{
ARAMEJSKA WERSJA KSIĘGI OZEASZA
}

Aramejski przekład Księgi Ozeasza wchodzi w skład Targumu Jonatana, który obejmuje zbiór Proroków z kanonu Biblii Hebrajskiej. ${ }^{1}$ Przyjmuje się, że razem z resztą ksiąg Proroków Mniejszych stanowi on jedną całość. ${ }^{2}$ Zgodnie z obiegową opinią, Targum Jonatana powstał w Palestynie na początku ery, a następnie został poddany redakcji w Babilonii, gdzie dostosowano go do lokalnych potrzeb, dzięki czemu osiągnął status oficjalny. ${ }^{3}$

Głównym celem aramejskich tłumaczy było to, by przekazać taki przekład ksiąg biblijnych, który byłby zrozumiały i jasny dla przeciętnego odbiorcy, jednocześnie targum powinien odpowiadać koncepcjom i interpretacjom teologicznym ówczesnego judaizmu. W tym celu meturgemani stosowali różnego rodzaju techniki translatorskie. Wśród nich zwraca uwagę stosowanie charakterystycznych terminów, określających Boga, a także akcent stawiany na rozwój pewnych koncepcji teologicznych. Często też teksty zawierające metafory tłumaczono w bardziej zrozumiały sposób. ${ }^{4}$ Targumiści dokonywali również aktualizacji przesłania tekstu biblijnego. $\mathrm{W}$ ten

1 W zbiorze Proroków znajdują się: Prorocy Wcześniejsi: Joz, Sdz, 1-2 Sm i 1-2 Krl i Prorocy Późniejsi: Iz, Jr, Ez i dwunastu proroków.

2 Szerzej na temat targumu Proroków Mniejszych zob. K. J. C a t h c a r t, R. P. G o r d o n, The Targum of the Minor Prophets, Aramaic Bible 14, Edinburgh 1989, s. 1-25; zob. też. P. V. M. F le s h e r, B. C h ilt o n, The Targums. A Critical Introduction, Waco 2011, s. 219-228.

3 M. M c N a m a r a, Interpretation of Scripture in the Targumim, w: A. J. H a u s e r, D. F. W a t s o n (red.), A History of the Biblical Interpretation, t. 1: The Ancient Period, Grand Rapids 2003, s. 168. Zdaniem Leveya, miało to miejsce między III a V w. na terenie Babilonii. S. H. L e v e y, The Date of Targum Jonathan to the Prophets, VT 21/1971, s. 186-196.

4 K. J. C a t h c a r t, R. P. G ord o n, The Targum of the Minor Prophets, s. 2. 
sposób w targumach pojawiają się informacje o miejscach, instytucjach, a nawet wydarzeniach, które nie miały miejsca w okresie powstawania Biblii, lecz należą do okresu znacznie późniejszego. ${ }^{5}$ Tłumacze aramejscy starali się przekazać tekst biblijny w taki sposób, by był on zgodny z aktualnymi poglądami rabinów.

Jednak zdarza się również, że aramejskie przekłady biblijne zawierają metaforyczne interpretacje tekstu, nawet jeśli nie wymaga tego znaczenie tekstu hebrajskiego. W ramach uzupełnienia takiej metaforycznej egzegezy mogą występować przykłady interpretacji alegorycznej.

Prezentowane niżej omówienie dotyczy aramejskiej wersji Księgi Ozeasza, proroka, który działał w Królestwie Północnym w okresie poprzedzającym upadek Samarii (722 r. przed Chr.). ${ }^{6}$ Ozeasz jest uznawany za pierwszego spośród tzw. proroków piszących, ponieważ jego wyrocznie zachowały się w formie spisanej. Targum do Księgi Ozeasza, podobnie jak pozostałe aramejskie tłumaczenia ksiąg zbioru Dwunastu, wpisuje się w nurt wczesnej egzegezy żydowskiej tej księgi.

$\mathrm{W}$ artykule zostaną przedstawione charakterystyczne różnice między przesłaniem tekstu hebrajskiego a przekładem aramejskim Księgi Ozeasza, ${ }^{7}$ które wynikają z przyczyn teologicznych. Szerzej zostanie przedstawiony przekład Targumu Ozeasza 1-3, ze szczególnym zwróceniem uwagi na te wersety, które bezpośrednio odnoszą się do małżeństwa Ozeasza. Małżeństwo to sprawiało spory kłopot

5 Tamże.

6 Początek działalności proroka przypada prawdopodobnie na panowanie Jeroboama II - czasy pomyślne spokojne (ok 750 r.), drugi etap (734-732) to czas wojny syro-efraimskiej, kontynuacja działalności to czas oblężenia asyryjskiego i próby szukania pomocy Izraela u Egipcjan, natomiast ostatni okres to czas ok 725 r., tuż przed oblężeniem Samarii.

7 Tłumaczenie i opracowanie Targumu Jonatana, które ukazało się w języku angielskim, obejmuje pięć tomów Aramaic Bible. The Targums (t. 10-14). Tom 14 to Targum Dwunastu Proroków Mniejszych, a w nim Targum Ozeasza opracowany przez K. J. Carthcarta i R. P. Gordona. Zob. K. J. C a th c a r t, R. P. G o r d o n, The Targum of the Minor Prophets, s. 31-62. 
tradycyjnym komentatorom żydowskim, co znalazło swój wyraz w słynnym fragmencie komentarza Abrahama ibn Ezry: „Rzekł Abraham [ibn Ezra]: Boże uchowaj, żeby to Pan miał pouczyć [proroka], aby za żonę pojął kobietę nierządną, a dzieci doczekał się z nierządnicy". 8

\section{Prorok Ozeasz i jego małżeństwo w targumie}

Księga Ozeasza rozpoczyna się od tytułu, w którym znajdują się informacje na temat czasu działalności proroka oraz odniesienia historyczne. ${ }^{9} \mathrm{~W}$ przekładzie aramejskim tytułu zachodzą niewielkie lecz charakterystyczne dla targumów zmiany: „Słowo proroctwa od

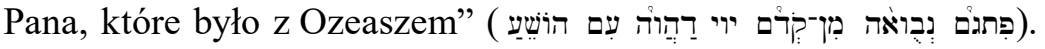

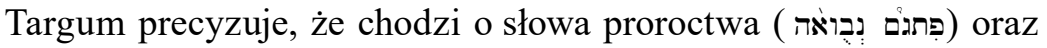

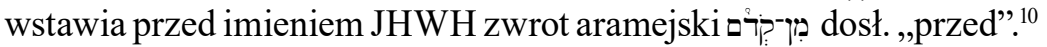
A następnie tłumacz dodaje słowo „dom” (רבית) W odniesieniu do Judy.

Następnie w tekście hebrajskim jest opowiedziana historia małżeństwa proroka Ozeasza z nierządnicą. Motyw ten pojawia się przede wszystkim w Oz 1,2-9 i 3,1-3. W wersji aramejskiej małżeństwo to zostało zinterpretowane alegorycznie. Obok Targumu do Pieśni nad pieśniami jest to najdłuższy fragment, który aramejscy tłumacze zinterpretowali alegorycznie.

\section{$\operatorname{Tg}$ Oz 1,2-9}

${ }^{2}$ Początek słowa Pańskiego z Ozeaszem: Pan rzekł do Ozeasza: „Idź i głoś proroctwo przeciw mieszkańcom bałwochwalczego miasta, którzy nieustannie grzeszą. Gdyż mieszkańcy tego kraju

8 A. Lip s hitz, The Commentary of Rabbi Abraham Ibn Ezra on Hosea, New York 1988, s. 20.

9 Por. np. Oz 1,1; So 1,1; Ha 1,1.

10 Zob. M. L. K 1 e i n, The Preposition Qdm (before): a Pseudo-Anthropomorphism in the Targums, JTS 30(1979)2, s. 502-507. 
odwrócili się od czci Pana". 'Poszedł więc i prorokował im, że jeśli okażą skruchę, zostanie im przebaczone; jeśli zaś nie, to upadną, jak opadają liście drzewa figowego. Oni jednak nadal popełniali grzeszne czyny. ${ }^{4}$ A Pan rzekł do niego: „Nazwij ich «Rozproszeni», bo oto już za niedługo pomszczę krew bałwochwalców, którą Jehu wylał w Jizreel, kiedy wydał ich na śmierć, bo oddawali pokłon Baalowi. Teraz oni sami odwrócili się, by oddawać cześć cielcom w Betel. Dlatego odpowiedzialności za krew niewinną zażądam od domu Jehu, i zabiorę królowanie z domu Izraela. ${ }^{5} \mathrm{~W}$ owym czasie zniszczę siłę wojowników Izraela w Dolinie Jizreel". 'Oni nadal popełniali grzeszne czyny, i rzekł do niego: „Nazwij ich «Nie-pożałowani» ze względu na ich uczynki. Bo nie będę miał więcej litości nad domem Izraela; jeśli jednak okażą skruchę, na pewno im przebaczę". ${ }^{7}$ Ulituję się nad ludem domu Judy i ocalę ich przez Memra Pana, ich Boga. Nie będą uratowani przez łuk ani przez miecz, ani przez wojowników, ani przez konie, ani przez jeźdźców. ${ }^{8} \mathrm{~A}$ ich mieszkańcy, rozproszeni wśród narodów, pójdą w zapomnienie, bo nie żałowali ze swe uczynki i nadal popełniali grzeszne czyny. ${ }^{9}$ Wtedy rzekł: „Nazwij ich imieniem «Nie-Mój-lud», bo nie jesteście Moim ludem, ponieważ nie wypełniacie słów Mego Prawa, Moje Memra nie były dla was oparciem".

\section{Komentarz}

W w.1,2 (TM) hebrajski rdzeń דבר jest użyty w formie czasownika w osnowie piel (,przemówił”). ${ }^{11} \mathrm{~W}$ przekładzie aramejskim początek w. 2 został uzupełniony o termin פתגמּז to jest ,słowo”, które zostało dodane przed imieniem JHWH, tak jak to ma miejsce w hebrajskim zwrocie ,słowo JHWH” ( רבר יהוה -1,1). Podobne uzupełnienia ma Septuaginta i Peszitta.

Materiał dodatkowy znajduje się w dalszej części tłumaczenia w. 2 oraz w. 3. Nakaz Boga z tekstu masoreckim 1,2, aby Ozeasz ,poszedł,

11 Osnowa piel wyraża intensywność, powtarzalność, co sugeruje, że może wskazywać, iż mówienie Boga do Ozeasza trwało długo i mogło mieć różne formy. 
wziął sobie żonę nierządnicę” ( אשֶׁת זְנוּנים , dosł. ,kobietę nierządów”,

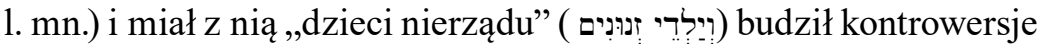
wśród rabinów. Pytali oni, jak Bóg mógł przekazywać takie polecenia prorokowi JHWH. Aramejski tłumacz rozwiązuje ten dylemat dokonując zmiany, mianowicie polecenie zawarcia małżeństwa zmienia

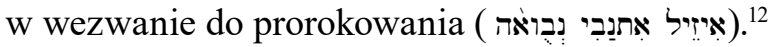

Następnie autor biblijny przechodzi do oceny religijno-moralnej kraju, który grzeszy przez nierząd, to znaczy bałwochwalstwo. W targumie misja proroka ma być skierowana do mieszkańców miasta,

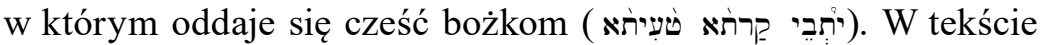
aramejskim użyto tu rdzenia טעי (טעה (także, który może znaczyć „wędrować”, „mylić się”, ,zapominać”, „błądzić”, „gubić się”, „dać się uwieść”, ,być wyuzdanym” a także „czcić bożki”. ${ }^{13} \mathrm{~W}$ targumach odpowiada on hebrajskiemu terminowi biblijnemu ,uprawiać nierząd" ( זנה por. Tg Am 7,17). ${ }^{14}$ A zatem targum interpretuje potrójną wzmiankę na temat nierządu (rdzeń זנה) w odniesieniu do kobiety, dzieci i kraju z tekstu masoreckiego w sposób symboliczny. Targu-

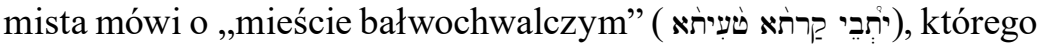
mieszkańcy „,ciagle grzeszą” (rdzeń (חט) i ,naprawdę odwrócili się

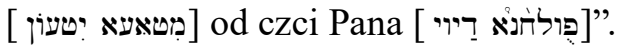

Przejście w tekście masoreckim od sytuacji małżeńskiej do oceny moralno-religijnej kraju usprawiedliwia symboliczne znaczenie losów proroka. W tym kierunku idzie interpretacja małżeństwa proroka przez aramejskiego tłumacza. Aby nie budzić wątpliwości w odbiorcy, translator już od początku fragmentu zamienia żonę proroka na miasto nierządne, w którym uprawia się bałwochwalczy kult,

12 Inne przykłady takiego zabiegu znajdują się Za 11,4.15. Należy zaznaczyć, że w manuskrypcie ze zbioru Montefiore Library, Jews College, London (Sperbera rękopis c) pojawia się długie uzupełnienie do $\mathrm{Oz} 1,2 \mathrm{w}$ postaci fragmentu znanego z b.Pes. $87 b$. Gdzie znajduje się zupełnie inna niż w targumie interpretacja małżeństwa proroka. Zob. L. S m o l a r, M. A b e r b a c h, Studies in Targum Jonathan to the Prophets, New York 1983, s. 43n.

13 M. J a s t row, A Dictionary of the Targumim, the Talmud Babli and Yerushalmi, and the Midrashic Literature, t. 1, London 1903, s. 542.

14 Tamże. 
a dzieci proroka stają się mieszkańcami tego miasta. Obraz bałwochwalstwa jako odejście od czci JHWH jest znany i dość często wystepuje w pismach prorockich. Tłumacze nawiązują do tego rodzaju interpretacji, wprowadzając dodatkowe informacje, dzięki którym unikają napięcia, jakie istnieje tekście hebrajskim. W wersji aramejskiej wypowiedź Boga nie odnosi się zatem bezpośrednio do sytuacji życiowej proroka, a samo polecenie nie jest już tak kontrowersyjne dla odbiorców.

Następnie, w Oz 1,3, prorok wykonuje polecenie Boga i rodzi mu się z tego związku syn. W tekście hebrajskim są także podane imiona żony proroka, czyli Gomer, i jej ojca Diblaima (בְת

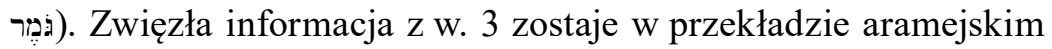
rozszerzona $w$ duchu interpretacji homiletycznej. ${ }^{15}$ Wersja aramejska, kontynuując myśl z poprzedniego wersetu, ukazuje misję Ozeasza jako prorokowanie do mieszkańców miasta. Głosi potrzebę skruchy, w wyniku której zostaną przebaczone ich grzechy. W ten sposób zostaje wprowadzony istotny temat obecny w judaizmie rabinicznym, mianowicie temat skruchy i przebaczenia. Następnie targumista stosuje metaforę, która ma obrazować, co się stanie z tymi, którzy nie wykażą skruchy: „Upadną, jak opadają liście drzewa figowego”

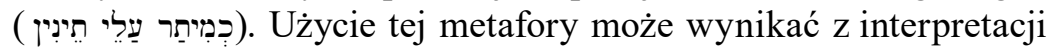

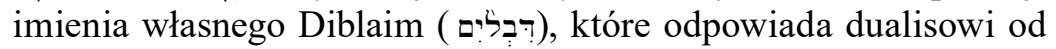
רבילה to znaczy ,ciastko ze sprasowanych fig” (por. b.Pes. 87b). ${ }^{16}$ Tłumaczenie tego wiersza kończy dodatek do tekstu hebrajskiego, który przekazuje, że mieszkańcy miasta nadal grzeszyli.

Kolejno tekst hebrajski przechodzi do sytuacji rodzinnej proroka, w której ważną rolę odgrywają symboliczne imiona dzieci $(1,4-7)$. W odniesieniu do nich przekład aramejski odchodzi od tekstu hebrajskiego. Kontynuuje natomiast myśl o popełnianych odstępstwach i bałwochwalstwie, uzupełniając i rozwijając niektóre wątki związane z karą, która spotka Izrael.

15 K. J. Cathcart, R. P. Gord o n, The Targum of the Minor Prophets, s. 29 , przyp. 10.

16 Tamże. 


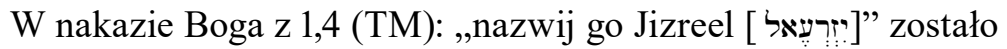
wymienione imię Jizreel, czyli „Bóg sieje”, które ma znaczenie symboliczne. W targumie imię to zostaje zmienione na Mewadraia

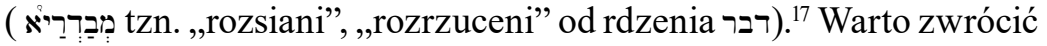
uwagę, że w wersji aramejskiej nie występuje element teoforyczny ('el), natomiast jest wzmianka do sytuacji rozrzucenia Izraela na wygnaniu. W następnych wersetach targum posługuje się jednak nazwą hebrajską odnośnie do miejsca. W tekście hebrajskim imię pierwszego syna Ozeasza nawiązuje bezpośrednio do doliny Jizreel i tego, co się w niej wydarzyło. Chodzi o aluzję do zamachu stanu, którego dokonał Jehu, przodek współczesnego Ozeaszowi Jeroboama II (zob. 2 Krl 9,11 - 10,36). Prorok zapowiada dokonanie przez Boga pomsty na domu Jehu i koniec monarchii. Ozeasz przyjmuje, że Jehu i jego następcy grzeszył tak samo jak ci, których zabił. Prorocy potępiają zawsze odstępstwa od Boga - idolatrię i apostazję oraz zgubne sojusze polityczne, czyli poleganie na sobie i na sojusznikach zamiast na Bogu. Jednak według 2 Krl 9-10 kiedy Jehu niszczył dom Ahaba, to działał z polecenia Boga, zatem Oz 1,4 stwarza pewien problem interpretacyjny, który trzeba by jakoś rozwiązać. Targum rozwija myśl zawartą w tekście biblijnym za pomocą różnego rodzaju uzupełnień, świadczących o tym, że ci, którzy zabili bałwochwalców, sami również zwrócili się do kultu fałszywych bożków („Baalowi”; „,cielcom w Betel”) i dlatego też musieli zostać odpowiednio ukarani. Tekst masorecki w kategoryczny sposób zapowiada kres królestwa ${ }^{18}$ natomiast targum łagodzi nieodwracalność tego sformułowania za pomocą użycia rdzenia בטל (,ustać” „usuwać”, ,zaprzestać”). ${ }^{19}$

17 Por. Dn 4, 11 ,rozrzućcie [ יוּבַדַרוּ] jego owoc”; w Biblii Hebrajskiej odpowiada mu rdzeń בזר. Dn 4,11. F. Brow n, S. R. Drive r, C. A. B rigg s, Enhanced Brown-Driver-Briggs Hebrew and English Lexicon, Oxford 1977, s. 1084.

18 Nie wiadomo, o jaki przedział czasowy chodzi, a dotyczy to Północnego Królestwa. Prorok podkreśla, że zagłada należy się już teraz, ale Bóg jakby wstrzymuje się.

19 Por. Ezdr 4,24. Zob. też formę hifil (הבטיל) w tekstach rabinicznych: M. J a s trow, A Dictionary of the Targumim, t. 1, s. 157. Zob. też: F. B row n, 
W w. 5 tekst hebrajski jest mowa o ,łuku” ( קשֶׁת), który jest symbolem siły męskiej i potencji ${ }^{20}$ i tak też rozumie to targumista, za-

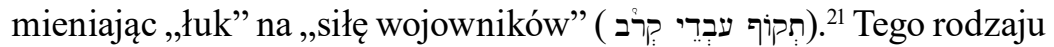
zmiany metafory są dość często stosowaną techniką translacyjną przez tłumaczy aramejskich.

W w. 6 targumista dodaje całe zdanie na temat tego, że ludzie grzeszyli. Choć nie ma wyraźnie wzmianki o kogo chodzi, zdanie przypomina w. 2, gdzie była mowa o mieszkańcach miasta bałwochwalczego. W tekście masoreckim znajduje się bezpośrednio informacja: „Ona zaś znów poczęła i urodziła córkę”, ale zgodnie z przyjętą alegoryczną linią interpretacyjną targum unika wzmianki o nierządnicy. Symboliczne imię córki w wersji aramejskiej brzmi podobnie, jednak zostaje uzupełnione objaśnieniem, dlaczego Bóg nie będzie miał miłosierdzia nad ludźmi, ,ze względu na ich uczynki”.

Następnie w tekście masoreckim występuje fraza „bo domowi Izraela nie okażę już więcej litości ani im nie przebaczę", którą targumista przekłada jako ,jeśli jednak okażą skruchę, na pewno im przebaczę”, stosując zasadę „tłumaczenia odwrotnego". ${ }^{22}$

Tekst w. 7 jest uzupełniony słowem ,lud”, kiedy jest mowa o domu Izraela, zabieg ten jest często stosowany w targumach (por. 1,1). W wersecie tym występuje również termin Memra, który jest użyty przed imieniem JHWH. W targumach jest to rzeczownikowe określenie zastępcze. ${ }^{23}$ Zastosowanie tego terminu jest charakterystyczną

S. R. D rive r, C. A. B rigg s, Enhanced Brown-Driver-Briggs Hebrew and English Lexicon, s. 1084.

20 Zob. Jr 49,35; Hi 29,20.

${ }^{21}$ Oznacza to zniszczenie mocy Izraela, prawdopodobnie podczas asyryjskiej inwazji w 733 r. Zdanie należy do przekleństw, dołącza innych do starożytnych przymierzy, być może więc zakłada spełnienie przekleństw, nieuchronny skutek złamania przymierza (zob. Pwt 28). Łuk rozumiany jako siła na zasadzie metonimii; por. Ha 3,9; Za 9,10; 10,4.

${ }^{22}$ K. J. C a t h c a r t, R. P. G or d o n, The Targum of the Minor Prophets, s. 30, przyp. 18.

${ }^{23} \mathrm{~W}$ aramejskich przekładach Memra pojawia się jako podmiot zdania w zastępstwie Bożego imienia lub jako zaimek w niemal wszystkich możliwych kontekstach. Termin ten może pochodzić z sformułowań typu: „Słowem Pańskim 
techniką przekładu aramejskiego. Meturgeman starał się w ten sposób unikać ukazywania bezpośrednio Boga, w tym przypadku chodzi o okazanie litości przez JHWH. Targumista stawia zatem Memra jako bezpośredni podmiot działania. W miejsce ,nie ocalę ich” (TM) z pierwszej części wiersza, Boże Memra stanie się narzędziem zbawienia dla ludzi z domu Judy. Na ile to jednak możliwe, targum unika przedstawiania Boga jako wojownika, co tłumaczyłoby też zmianę w tym fragmencie wiersza 1. osoby na 3. osobę i opuszczenie sugestii, jakoby Bóg występował na polu walki, posługując się orężem wojennym. ${ }^{24}$ Ponadto zachodzi niewielka zmiana w przekładzie

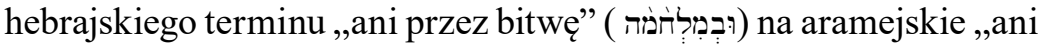

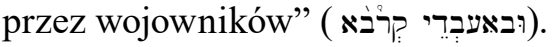

W w. 8 autor biblijny ukazuje upływ czasu za pomocą obrazu odstawienia od piersi i narodzin następnego dziecka. Targumista zastępuje go stwierdzeniem na temat popełniania grzesznych uczynków i kary, która spotka rozproszonych, czyli mieszkających na wygnaniu

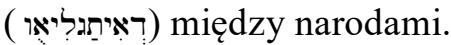

Wersja aramejska w. 9, zawierająca nakaz nadania imienia synowi proroka i znaczenie tego imienia, pokrywa się z tekstem biblijnym. Zmiana występuje w zakończeniu w. 9, który w tekście masoreckim

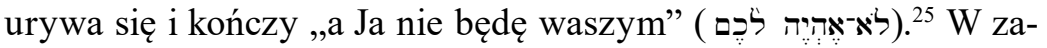
kończeniu targum nie tylko odsuwa nieodwracalny charakter zwrotu „nie jesteście Mym ludem”, lecz wprowadza inne odniesienie, mianowicie odwołuje się do Prawa (dosł. „Mego Prawa” - aram. אוֹרִיחת).

stworzone zostały niebiosa, wszystkie ich zastępy oddechem ust Jego" (Ps 33,6). Paralele tej idei znajdują się też w stwierdzeniach literatury wczesnorabinackiej typu: „Dziesięcioma wypowiedziami stworzony został świat” (m.Abot 1) oraz w błogosławieństwie liturgicznym: „Ten, który swoim słowem stworzył niebiosa” (b.Sanhedrin 42a). M. K le i n, Anthropomorphism and Anthropopathism in the Targums of the Pentateuch, Jerusalem 1982, s. 172.

${ }^{24}$ L. S m o l a r, M. A b e r b a c h, Studies in Targum Jonathan to the Prophets, s. $146 \mathrm{n}$.

25 W aparacie krytycznym pojawia się uwaga, aby czytać w tym miejscu „waszym Bogiem”. Prawdopodobnie taka stanowcza wypowiedź, zawierająca ostateczne odrzucenie, stwarzała problem doktrynalny kopistom. 
Jednocześnie nawiązuje do aktualnego nieprzestrzegania Prawa, podkreślając, że jedynie skrucha i nawrócenie mogą zmienić sytuację. Użyty w targumie termin אוריתא (tzn. ,prawo”, „nauczanie”) w tym wierszu wprowadza całą serię wzmianek o poznawaniu i wypełnianiu lub niewypełnianiu Prawa. ${ }^{26} \mathrm{~W}$ hebrajskiej Księdze Ozeasza motyw przestrzegania Prawa pojawia się, ale zostaje wprowadzony nieco później i tylko w Oz 4,6; 8,1.12. ${ }^{27}$

\section{Tg Oz 3,1-3}

'Pan znowu rzekł do mnie: „Idź i głoś proroctwo o domu Izraela, który jest jak kobieta poślubiona mężowi, ale go zdradza. Jak on ją kocha i nie chce jej odesłać, tak Pan miłuje lud Izraela, mimo że zwracają się do bałwanów narodów. Jeśli jednak będą żałować, zostanie im przebaczone i staną się jak człowiek, który popełnił błąd i powiedział coś odurzony winem. ${ }^{2} \mathrm{~A}$ Ja ich wyzwoliłem przez Moje Memra 15. dnia miesiąca Nisan, i dałem za nich srebrnego szekla wykupu, i powiedziałem, żeby przynieśli przede Mnie omer z ofiary ze zbiorów jęczmienia”. ${ }^{3} \mathrm{O}$ proroku, powiedz im: „Zgromadzenie Izraela, wasze grzechy spowodowały, że poszliście na wygnanie na wiele dni. Gorliwie składajcie Mi cześć, nie zbaczajcie z drogi, nie oddawajcie czci bałwanom - wtedy Ja również okażę wam miłosierdzie".

\section{Komentarz}

Symboliczna interpretacja sytuacji rodzinnej kontynuowana jest w aramejskiej wersji Oz 2. Jednak przede wszystkim jest to widoczne ponownie właśnie $\mathrm{Tg} \mathrm{Oz}$ 3,1-3.

W Oz 3,1 (TM) zostaje wprowadzony ponowny nakaz skierowany do proroka: „Idź, pokochaj jeszcze raz kobietę, która kocha innego i cudzołoży, tak jak JHWH kocha synów Izraela, chociaż zwracają

26 Por. Tg Oz 2,1.3.5.16.17; 4,6.14; 5,4.6.9; 7,16; 8,1.12; 10,1.12; 11,7; 13,9.14.

27 Zob. L. S m ol a r, M. A b e r b a c h, Studies in Targum Jonathan to the Prophets, s. 159-164. 
się ku innym bogom i lubią placki z rodzynkami”. Pojawiają się te same problemy interpretacyjne, które powstały przy Oz 1,2. Targumista ponownie mówi o misji proroka, która polega na głoszeniu proroctwa o domu Izraela, który porównuje do żony, zdradzającej męża. W targumie jest mowa o przebaczeniu, jeśli Izrael wykaże skruchę. W targumie zostaje dodaje jeszcze uzupełnienie tej sytuacji.

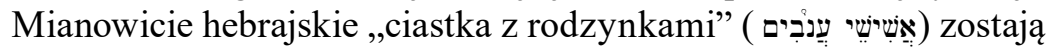

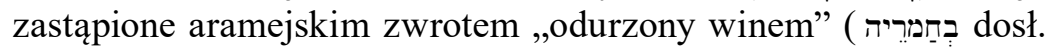
„w swoim winie”). ${ }^{28}$ A co za tym idzie, wykroczenie, o których jest mowa w wersecie, targum klasyfikuje jako ,grzech nieświadomości”. ${ }^{29}$

W Oz 3,2 jest mowa o tym, że kobieta została wykupiona ,za piętnaście srebrników i za półtora chomera jęczmienia". Targumista podaje symboliczną interpretację liczby piętnaście i odnosi ją do daty wyjścia z Egiptu, czyli do 15 . Nisan. ${ }^{30}$ Ponownie zostaje użyty termin Memra, kiedy jest mowa o działaniu JHWH, który wyzwolił lud przez swoje Memra.

W tekście biblijnym wątek małżeństwa kończy się w Oz 3,3: „I powiedziałem jej: «Przez wiele dni będziesz mieszkać w domu jako Moja, nie będziesz uprawiać nierządu, nie będziesz należała do innego mężczyzny ani ja do ciebie»". W wersji aramejskiej ponownie jest mowa o zgromadzeniu Izraela i o karze za oddawanie czci obcym bogom, którą będzie wygnanie z ziemi Izraela.

Wątek ten pojawił się już 2,1, gdzie początek Oz 2,1 to tłumaczenie dosłowne, natomiast druga część stanowi rozwinięcie tekstu

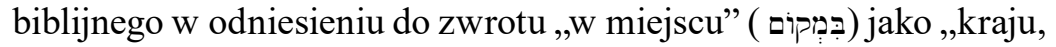

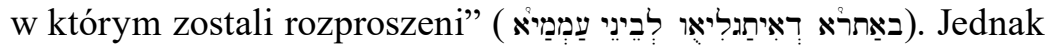
kara wygnania wymierzona za przekraczanie Prawa ( אוֹריתא Oz 7,4; 10,1) dobiegnie końca, wygnańcy powrócą i wzrosną w siłę.

28 Por. b.Pes. 36b i Lb Rabbah 4,20 interpretują jako ,butelki z winem”.

${ }^{29}$ K. J. C a t h c a r t, R. P. G or d o n, The Targum of the Minor Prophets, s. 35, przyp. 1.

30 Podobnie b.Hull. 92a; Num. Rab. 13,20. 
Przedstawiona analiza skoncentrowana była na interpretacji małżeństwa Ozeasza i nie odnosi się do wszystkich zmian, jakie wprowadzali aramejscy tłumacze w swoim przekładzie.

\section{Teologiczne przesłanie w Targumie Ozeasza}

Targum Ozeasza, podobnie jak cały Targum Jonatana, prezentuje pewne poglądy teologiczne, których brak jest w tekście masoreckim. Meturgemani starają się dostosować tekst przekładu do aktualnych im poglądów, wprowadzając zmiany w wersji aramejskiej Księgi Ozeasza. Zmiany te dotyczą sposobu mówienia o Bogu, a także relacji Bóg-człowiek.

Tłumacze aramejscy byli wyczuleni na niewłaściwe wyobrażenia o Bogu. W tym celu stosowali kluczowe terminy i pojęcia teologiczne. Każde stwierdzenie potencjalnie narażone na błędne zrozumienie stało się przedmiotem zmiany w takim zakresie, jaki wydawał się niezbędny do zaakceptowania od strony teologicznej. W odniesieniu do opisów Boga, aramejscy tłumacze wykazują skłonność do odrzucania antropomorficznych wyrażeń odnoszących się do Boga, stosują m.in. terminy zastępcze w mówieniu o Bogu.

Dla targumistów wiara w jedyność i transcendencję Boga Izraela ma znaczenie nadrzędne i priorytetowe. ${ }^{31}$ On rządzi historią i losem ludzi. Na każdym kroku i w różnej formie podkreśla się zarazem odrębność Boga i człowieka - w tym celu wielokrotnie użyte zostają różne terminy teologiczne.

\section{Memra}

Boże Memra raz funkcjonuje jako Jego wysłannik, kiedy indziej jako pośrednik między Nim a światem, tak że kiedy Bóg przemawia lub działa, dzieje się to ,przez Jego Memra” (por. Oz 3,2). ${ }^{32}$

31 L. S m o la r, M. A b e r b a c h, Studies in Targum Jonathan to the Prophets, s. 129 n.

${ }^{32}$ Zob. Tg Oz 5,8.14 (2x); 6,7; 7,13.14; 10,9.10; 14,9 (2x). 
Stosowanie tego terminu odzwierciedla poszczególne elementy doktryny, którą przekazuje Targum Jonatana. Jednym z nich jest niemożność porównania Boga do czegokolwiek innego. Przykład takiego tłumaczenia występuje w Oz 14,9b, gdzie Bóg porównany zostaje do ,wiecznie zielonego cyprysu”. Targum Jonatana zmienia to wyrażenie na: „Przez Moje Memra upodobnię go [Efraima = Izraela] do pięknego cyprysu".

Targum kładzie szczególny nacisk na to, że wszystko, co dzieje się na świecie, Bóg ma pod kontrolą, zarządza tym i tak naprawdę sam to wywołuje. Por. Oz 8,4a: TM „Wybierali królów, ale nie przeze Mnie”, które w wersji aramejskiej zostaje zmienione na „Wybierali królów, ale nie przez Moje Memra”. Podobnie Tg Oz 10,10: „Przez Moje Memra zesłałem na nich karę i zgromadziłem przeciw nim narody". W powyższym przykładzie zachodzi jeszcze jedna zmiana w Oz 10,10b. „I zgromadzą się przeciw nim wszystkie narody” (TM) w targumie zostaje zmienione na: ,I zgromadzę przeciw nim wszystkie narody (imperfect passive zamieniony na perfect active). Zmianie czasu mogła w zamierzeniu towarzyszyć chęć uniknięcia zapowiedzi przyszłej klęski. Bóg jest zatem tym, który determinuje historyczny bieg wydarzeń, a rzeczy nie dzieją się ot tak, po prostu.

\section{Szekina}

Podobnie jak Memra termin Szekina (שִִִינה) należy do charakterystycznych terminów stosowanych przez targumistów. ${ }^{33} \mathrm{Za} \mathrm{jego} \mathrm{po-}$ średnictwem wyrażali oni przekonanie o Bożej obecności wśród Jego ludu, nie ujmując nic z prawdy o Jego transcendencji. Podobnie, jak w całym Targumie Jonatana, tak w Targumie Ozeasza pobrzmiewa przekonanie, że końcowa odpłata Izraelowi za grzechy polegać będzie na odejściu Szekina, np. Tg Oz 2,5a: W przeciwnym razie „usunę Moją Szekina spośród nich i odbiorę im chwałę". W TM 2,5 jest mowa

33 Szerzej zob. M. M c N a m a r a, Targum and Testament Revisited: Aramaic Paraphrases of the Hebrew Bible: A Light on the New Testament, Grand Rapids $2010^{2}$, s. 146-153. 
o porzuceniu córki w dniu urodzin, które ukazuje jednoznacznie odrzucenie. Targum zaś przedstawia sytuację w łagodniejszy sposób, bo choć zapowiada największą sankcję i karę wymierzoną Izraelowi za jego przewinienia, jaką jest groźba JHWH, że usunie spośród ludu swoją Szekina, to jednak nawiązuje do sytuacji, która miała już kiedyś miejsce na pustyni, a zatem nie jest to decyzja ostateczna. ${ }^{34}$

W targumie występuje termin Szekina także w kontekście kraju, np. 2,25: „Ustanowię cię przed sobą w kraju domu Mojej Szekina(h) i ulituję się nad tymi, nad którymi [nikt] się nie litował z powodu ich uczynków". ${ }^{35}$

Wiele fragmentów Targumu Jonatana zakłada atrybut wszechobecności Boga, choć nie stwierdza tego wprost. I tak „miejsce” z Oz 5,15a: „I powrócę na Moje miejsce” w Tg Oz: „Zabiorę Moją Szekina, wrócę do Mej świętej siedziby w niebiosach, póki nie uświadomią sobie, że są winni, i nie będą Mnie błagać. Kiedy znajdą się w utrapieniu, będą szukać Mej bojaźni”.

Targum Jonatana starannie unika przekładów literalnych wskazujących, że Bóg był „blisko” lub „daleko”, względnie że można Go „poszukiwać” lub „odnaleźćc, ewentualnie że jest Bogiem ograniczonym do jakiegoś terytorium, np. w Oz 9,3a: TM ,ziemia Pana”, które w Tg Oz zostaje zmienione na „ziemia Szekina Pańskiej”.

\section{Wszechwiedza Boga}

Targumiści starali się także podkreślić wszechwiedzę Boga, obejmującą wszystkie myśli i czyny człowieka. Targum zakłada zatem, że niedopuszczalne jest mówienie o Bogu, w taki sposób, że mógł czegoś nie wiedzieć, zatem zmienia to w przekładach w odpowiedni sposób. np. Oz 8,4a: TM „Ustanawiali książąt, lecz bez Mojej wiedzy”; staje się w targumie „Ustanawiali książąt, lecz nie wedle Mojej woli”. Fragment Oz 13,5a TM: „Poznałem cię na pustyni” (dopuszczając

34 Por. K. J. C a t h c a r t, R. P. G or d o n, The Targum of the Minor Prophets, s. 31 .

35 Termin Szekina występuje także w Tg Oz 5,15; 9,12; 11,9; 13,14. 
możliwość, że Bóg nie poznał Izraela gdzie indziej) w Tg Oz jest oddane jako „Na pustyni zaspokajałem twoje potrzeby”. Atrybut wszechwiedzy wyklucza także możliwość ,zapominania” lub ,przypominania sobie” przez Boga, np. Oz 4,6b TM: „Zapomnę o twoich dzieciach” w Tg Oz jest zmienione na „Odrzucę twoje dzieci”.

\section{Oddawanie czci i bojaźń}

Innymi ważnymi terminami o znaczeniu teologicznym w Targumie Jonatana są także pulhana' ( פלדנא ) - ,oddawanie czci”, ,liturgia” i dahleta' ( דחלה) - „strach”, ,bojaźń”, których funkcję zastępczą można zilustrować mnóstwem przykładów. W Tg Oz szczególnie przydatne są w tym względzie Oz 14,2 TM: „Wróć, Izraelu, do Pana Boga twojego”, w Tg Oz: „Powróć, o Izraelu, do bojaźni przed Panem, twoim Bogiem” i Oz 14,3, TM: „....nawróćcie się do Pana” w Tg Oz: „...powróćcie do oddawania czci Panu”. Zastosowanie obu terminów w bliskim kontekście ukazuje wzajemne współgranie obu pojęć.

W rozumieniu Targumu Jonatana bałwochwalstwo jest grzechem. Za niewybaczalną winę Izraela spotka nieuchronna kara - utrata wolności, przepadek majątku na rzecz wrogów Izraela i wygnanie $\mathrm{z}$ ziemi rodzinnej. Zgodnie z targumiczną interpretacją $\mathrm{Oz} \mathrm{10,5a,}$ przyczyną deportacji Izraela było właśnie oddawanie czci cielcowi w Betel. Wersję hebrajską targum rozszerza homiletycznie: „Ponieważ w Betel czcili cielce, powstanie przeciw nim król wraz ze swoją armią i uprowadzi ich w niewolę. I zabiorą im cielca z Samarii”. Charakterystyczne, że nawet nie-Żydzi, którzy przecież nie podlegali prawu przymierza $z$ Bogiem, też mogą zaciągnąć winę naznaczoną karą, a mianowicie za swoje bałwochwalstwo i okazywane zuchwalstwo.

Teologiczna ortodoksja Targumu do Proroków wyraża się w trosce o unikanie jakiejkolwiek nieprawidłowości w sprawach kultycznych. Targum Ozeasza przedstawia bałwochwalstwo zgodnie z przekonaniami religijnymi, które są przekazane w całym Targumie Jonatana. Bałwochwalstwo jest grzechem i doznaje zrównania z wszystkimi innymi grzechami. Nieuchronna kara spotka Izraela za niewybaczalną 
winę - utrata wolności, przepadek majątku na rzecz wrogów Izraela i wygnanie z ziemi rodzinnej. ${ }^{36}$

\section{Tora}

W opinii rabinów najlepszym sposobem na uniknięcie grzechu jest oddanie się studium Tory (aram. אוֹרִיתא). Targum Jonatana w pełni podziela to zdanie i wielokrotnie podkreśla rangę i znaczenie studiowania i nauczania Tory. ${ }^{37}$ Ponieważ w Torze Bóg sam zostawił Izraelowi pouczenia: Tg Oz 5,9b: „Pokoleniom izraelskim dałem poznać Torę” (por. TM: „Przeciw pokoleniom Izraela podaję zapowiedź pewną"). Izrael winien być jej poddany - Bóg z kolei wynagrodzi to Izraelowi, spełniając dla swego ludu cudowne dzieła; por. Tg Oz 2,16a: „I poddam ją Torze, i wykonam dla niej cuda i czyny potężne, tak jak uczyniłem jej na pustyni”.

Sprawiedliwi, którzy poświęcą się studiowaniu Tory, zostaną sowicie wynagrodzeni. Stale wzbogacać się będą w nową wiedzę, mądrość i bogactwa, a Bóg wysłucha ich modlitw. W sytuacji odwrotnej odmowa studiowania Tory i stosowania się do niej stanowi akt buntu i nieposłuszeństwa. Może się za to spodziewać słusznej kary: Tg Oz 4,14b: ,... pokolenie, które nie rozmyśla nad Torą - czyż nie będzie porzucone?" O ile nieznajomość Tory jest wybaczalna, o tyle nie ma usprawiedliwienia dla człowieka, który nie chce prosić o pouczenie, względnie nie przyjmuje go, kiedy takie otrzymuje takie postępowanie zasługuje na ostrą reprymendę proroków - por. Tg Oz 5,4b „Nie prosili o pouczenie od Pana”.

Praktycznie ujmując sprawę, bojaźń Boża oznacza skrupulatne przestrzeganie zasad zapisanych w Torze. Kiedy Izrael je wypełnia, to w różnorodny sposób spotyka go nagroda. Przynosi wtedy obfity

36 Z perspektywy okresu talmudycznego prawdziwa idolatria już dawno przestała stanowić zagrożenie dla przetrwania judaizmu, ale w czasach prześladowań mogła zachwiać ludźmi o słabym charakterze, którzy mogli ulec światu pogańskiego

37 L. S m ol a r, M. A b e r b a c h, Studies in Targum Jonathan to the Prophets, s. 160 . 
plon jak winnica zasadzona przy źródle - Tg Oz 10,1a: „Zepsutym winem jest Izrael, lecz kiedy wypełniali Torę, był winem wybornym". Tg Oz 9,13a: „Kiedy zgromadzenie Izraela wypełnia Torę, jest niczym Tyr w okresie świetności i szczęścia”.

\section{Modlitwa}

Istotne miejsce w targumach zajmuje także modlitwa. ${ }^{38}$ Oprócz regularnych nabożeństw występuje jeszcze mnóstwo innych okazji do zanoszenia modlitw nadzwyczajnych, przede wszystkim w czasach utrapienia, np. Tg Oz 8,2: „A kiedy sprowadzę na nich utrapienie, będą się modlić do Mnie i powiedzą: «Teraz wiemy, że nie mamy Boga prócz Ciebie. Przyjdź nam z pomocą, bo jesteśmy Izraelem, Twoim ludem!»".

Targumy przekazują wskazania, kiedy modlitwa jest skuteczna, winno ją poprzedzać prawdziwe nawrócenie. Tg Oz 2,4: „Zgań zgromadzenie Izraela i powiedz mu, że nie przykłada się do oddawania Mi czci, dlatego Moje Memra nie przyjmie ich modlitw, póki wpierw nie usunie sprzed swego oblicza grzesznych uczynków".

\section{Era mesjańska}

Targum Ozeasza zapowiada nastanie ery mesjańskiej już w symbolicznej interpretacji imion dzieci z Oz 2,1b: „A zamiast ich nazywać: «Lud nie mój», będą im mówić: «Dzieci żyjącego Boga»”; Tg Oz 2,1b-2: „A z k raju, gdzie poszli na wygnanie wśród narodów, gdy

38 Szerzej na temat znaczenia modlitwy zob. M. M a h e r, The ,meturgemanim” and Prayer, JJS 41(1990)2 s. 226-246, M. B a r a n i a k, Słowo „,modlitwa” [şlw/ şly] $w$ aramejskich targumach do Biblii Hebrajskiej - z perspektywy tekstów palestyńskich (II w.p.n.e. -I w. n.e. oraz VIII w. n.e.), w: A. R ó ż yło (red.) Modlitwa w językach i tekstach artystycznych, Sandomierz 2007, s. 35-53; A. K u ś m i r e k, „Zbawienie mej duszy nastapi dzięki modlitwie do Pana” (TgJon 2,10b). Rola modlitwy w targumach, w: W. C h r o s t o w s k i (red.), „Jak śmierć potężna jest miłośc’.' Księga pamiątkowa ku czci Księdza Profesora Juliana Warzechy (19442009), Warszawa 2009, s. 250-258. 
przekroczyli Prawo, i gdzie im powiedziano: «Nie jesteście Mym ludem», powrócą i staną się wielcy. I powiedziane im będzie: «Lud żyjącego Boga»". W następnym wersecie Tg Oz 2,3 dodaje, że chodzi o przywódcę z ,domu Dawida”. Natomiast w Tg Oz 3,5, jest mowa wyraźnie o przyjściu Mesjasza ,i będą posłuszni Pomazańcowi, synowi Dawida, ich królowi”. Idea posłuszeństwa Mesjaszowi, synowi Dawida, opiera się najwyraźniej na Rdz 49,10, tak jak tłumaczy to $\mathrm{TgO}$ (por. Tg Iz 11,10; Jr 30,9). ${ }^{39}$

Targum Księgi Ozeasza, podobnie jak księga biblijna, przekazuje nadzieję na przyszłość i mówi o przyjściu dni, kiedy zostanie odbudowany dom Dawida. Jednak Targum mówi wyraźnie, że Bóg odbuduje królestwo Dawida i miasta oraz ustanowi od nowa zgromadzenie sprowadzi liczne wojska oraz sprowadzi wygnanych.

W epoce mesjańskiej nastąpi zmartwychwstanie, ślad tego ogólnego przekonania zawiera $\mathrm{Tg} \mathrm{Oz} \mathrm{6,2:} \mathrm{„On} \mathrm{wskrzesi} \mathrm{nas} \mathrm{na} \mathrm{dni}$ pocieszenia, które nadejdą w przyszłości, podniesie nas w dniu zmartwychwstania umarłych i żyć będziemy przed Nim”. Wspomniane tu „dni pocieszenia” nawiązują niewątpliwie do ery mesjańskiej. W ten sposób targum interpretuje tekst hebrajski: „Po dwu dniach przywróci nam życie, a dnia trzeciego nas dźwignie i żyć będziemy w Jego obecności”.

Od czasu końca Drugiej Świątyni judaizm faryzejski i rabinacki na krok nie odstępowały od wiary w karę ognia piekielnego dla grzeszników. Oparta na wielu tekstach Starego Testamentu ${ }^{40}$ idea ognistej kary dla grzeszników wyraźnie przewija się w późnej literaturze apokryficznej. Jednakże tylko w literaturze rabinackiej spotykamy próby bardziej precyzyjnego zdefiniowania grzechów, za które grozi kara Gehenny, czas jej trwania oraz metody jej uniknięcia dzięki okazanej skrusze, świadczonej dobroczynności itd. W Tg Oz pojawia się stwierdzenie, że grzeszników spotka kara w Gehennie, Tg Oz 14,10b: ,... lecz grzesznicy dostaną się do Gehenny, bo nie kroczyli drogami Pańskimi”. W tym ostatnim fragmencie przekład targum

39 K. J. C a th c a r t, R. P. G ord o n, The Targum of the Minor Prophets, s. 35.

40 Zob. np. Pwt 32,22; Iz 33,14; 66,24. 
zmierzał do uniknięcia potencjalnego nieporozumienia, ponieważ w brzmieniu dosłownym tekst ten zdaje się sugerować, że występni „potkną się”, kiedy będą kroczyć drogami Pańskimi. Targum prostuje w tym miejscu, że grzesznicy doświadczą kary, bo tymi ścieżkami po prostu nie chodzili. ${ }^{41}$

W targumie sprawiedliwość Boga nie podlega dyskusji. Tak naprawdę istnieje bowiem sprawiedliwość doskonała, nieodwołalna Tg Oz 6,4a: „W obliczu prawdziwego sądu co mam uczynić dla ciebie, domu Judy?" Innymi słowy, prorok jest bezsilny, by występować przeciw Boskiemu werdyktowi.

Jedna z najważniejszych zasad teologii rabinackiej brzmiała „miara za miarę”, czyli danej osobie przysługuje nagroda lub grozi kara ściśle odpowiadająca jej zasługom lub winie. Interpretację wielu fragmentów z Targumu Jonatana przeprowadza właśnie na bazie tej zasady, w Tg Oz potwierdza to $\mathrm{Tg} \mathrm{Oz} \mathrm{4,9a:} \mathrm{„A} \mathrm{stanie} \mathrm{się,} \mathrm{że} \mathrm{jak}$ pozwalali na to, by osoba świecka i kapłan bezcześcili Moje święte ofiary, tak Ja zniszczę twą cześć i uczynię mu to, co godne wzgardy”.

Nawet zabicie bałwochwalcy może zasługiwać na karę, jeśli winni takiego czynu sami oddają się kultowi; por. Tg Oz 1,4b: „Ja upomnę się o krew bałwochwalców, którą Jehu rozlał w dolinie Jizreel, ponieważ oddawali cześć Baalowi (zob. 2Krl 10,11). Oto teraz sami odwrócili się [ode Mnie] i zeszli na manowce za cielcami Betel. Dlatego właśnie domowi Jehu policzę to jako przelanie krwi niewinnej”.

Przedstawione powyżej elementy doktryny są obecne w całym Targumie Jonatana. Wskazane przykłady odnoszą się jednak jedynie do Targumu Ozeasza. Podobnie jak w przypadku alegorycznej interpretacji małżeństwa proroka w targumie, również w prezentowanych zagadnieniach teologicznych widać wpływ poglądów rabinów. $\mathrm{Z}$ drobnymi wyjątkami teologia Targumu Jonatana jest identyczna z ortodoksyjnym judaizmem, tak jak ukształtował się on wśród

${ }^{41}$ K. J. Ca t h c a r t, R. P. G o r d o n, The Targum of the Minor Prophets, s. 62. 
faryzeuszy i rabinów. Biblia często zawiera koncepcje i poglądy, które w późniejszym czasie rabini odrzucili, Targum Jonatana, jako dzieło powstałe w celu religijnego zbudowania rzesz wiernych, znacząco zmienia przekład, mając na celu wyeliminowanie wszelkich śladów teologii nieortodoksyjnej. ${ }^{42}$

Anna KUŚMIREK

Slowa kluczowe: Targum Ozeasza, małżeństwo, Targum Jonatan, przekład aramejski

Key words: Targum Hosea, marriage, Targum Jonathan, aramaic translation

\section{The Aramaic Version of the Book of Hosea}

\section{Summary}

The chief aim of this article is to show the key features of the Aramaic version of the Book of Hosea, that is a part of the Targum Jonathan. The first section of the research is the translation of a few passages of Targum Hos 1-3. On the basis of these translations, the allegorical meaning of the marriage of the Prophet in the targumic interpretation is shown. These are also some features of targumic renderings. The second part of the article discusses the most important aspects of the theological concept of Targum Jonathan based on examples from Targum Hosea.

${ }^{42}$ L. S m o la r, M. A b e r b a c h, Studies in Targum Jonathan to the Prophets, s. 129. 